\title{
SIFAT SENSORIS GEPLAK ROSELA (Hibiscus sabdariffa)
}

\section{SENSORY CHARACTERISTICS OF ROSELLE GEPLAK (Hibiscus sabdariffa)}

\author{
Yustina Wuri Wulandari ${ }^{1)}$, Indrias Tri Purwanti ${ }^{1)}$, Akhmad Mustofa $^{1)}$ \\ ${ }^{1)}$ Staf Pengajar Jurusan Teknologi Hasil Pertanian UNISRI Surakarta
}

\begin{abstract}
Roselle (Hibiscus sabdariffa) is one of horticulture plants. The special quality of roselle from Jelok is the organic product. Diversification of roselle handling is required in post harvest. Geplak is one of traditional food from Bantul, Yogyakarta. Roselle has potential effect for health. Therefore, the aims of this research were to find the formula of roselle geplak and to analyze sensory characteristics of the product.
\end{abstract}

Key words: geplak, rosella, sensory

\begin{abstract}
Abstrak
Rosella (Hibiscus sabdariffa) adalah salah satu tanaman hortikultura. Kualitas khusus rosella dari Jelok adalah merupakan produk organic. Diversifikasi penanganan rosella diperlukan pada pascapanen. Geplak merupakan salah satu makanan tradisional dari Bantul, Yogyakarta. Rosella memiliki efek potensial pada kesehatan. Oleh karena itu, tujuan penelitian ini adalah untuk menemukan formula geplak rosella dan untuk menganalisis sifat sensoris geplak rosella.
\end{abstract}

Kata kunci : geplak, rosella, sensoris

\section{PENDAHULUAN}

Geplak adalah makanan yang terbuat dari parutan kelapa dan gula pasir atau gula merah (Anonim, 2007). Rasa geplak manis dengan komposisi 50\% gula dan 50\% kelapa. Gula yang terdapat di dalam geplak selain digunakan sebagai pembuat rasa juga untuk pengawet geplak (Susanto, 1994).

Geplak juga merupakan adalah makanan khas kota Bantul, namun ada pula yang menyebut sebagai makanan Betawi dengan tambahan bahan berupa tepung beras dan daun jeruk purut. Terdapat pula geplak yang dibuat dari waluh. Industri geplak umumnya dapat ditemui di daerah Bantul, Yogyakarta, yang kebanyakan diusahakan oleh industri rumah tangga. Selanjutnya jenis makanan ini berkembang meluas akibat permintaan pasar dan diusahakan tidak hanya di sekitar kota Yogya tetapi juga di seluruh nusantara.

Pada perkembangannya proses pembuatan geplak ditambahkan bahan lain untuk penganekaragaman produk geplak. Salah satu bahan yang bisa ditambahkan adalah kelopak bunga rosela. Standar mutu geplak adalah kadar air maksimum 14\%, tidak ada penambahan pewarna sistetis, asam lemak bebas maksimum 0,50\% (Anonim, 1972).

Kelopak bunga rosela (Hibiscus sabdariffa Linn) merupakan bunga tunggal berwarna merah. Kelopak ini sering dianggap sebagai bunga oleh masyarakat. Bagian inilah yang sering dimanfaatkan sebagai bahan makanan dan minuman (Maryani dan Kristiana, 2005). Hal ini dikarenakan warna kelopak bunga yang merah dan mempunyai rasa asam. Kesadaran pola hidup sehat juga menjadi salah satu alasan pemilihan kelopak bunga rosela untuk bahan makanan ataupun minuman.

Beberapa penelitian tentang efektifitas rosela sebagai tanaman obat telah dilakukan, baik pada hewan maupun manusia. Herrera (2004) melaporkan bahwa kelopak bunga rosela dengan mampu menurunkan tekanan darah yang tidak berbeda nyata dengan pemberian captopril $50 \mathrm{mg} /$ hari. Sedangkan penelitian Kirdpon (1994) menyimpulkan bahwa mengkonsumsi jus kelopak rosela 16$24 \mathrm{~g} / \mathrm{dl} / \mathrm{hari}$ mampu menurunkan kreatin, asam urat, sitrat, tartat, kalsium, natrium, dan fosfat dalam urine. Penelitian Chen (2003) pada kelinci percobaan menunjukkan terjadinya penurunan kadar trigliserida, kolesterol dan low-density liponrotein cholesterol (LDL-C), hal serupa jug 5 i sama dalam penelitian Odigie (2003) bahwa dengan pemberian ekstrak kelopak rosela dengan dosis $250 \mathrm{mg} / \mathrm{hari} / \mathrm{kg}$ berat badan tikus menunjukkan adanya penurunan tekanan darah. 
Dilatar belakangi potensi kelopak rosela dan keberadaan geplak sebagai makanan tradisional, maka dilakukan diversifikasi olahan geplak yaitu geplak rosela. Oleh karena itu dalam penelitian ini dikaji analisis sensoris dari geplak rosela. Luaran yang diharapkan adalah diperoleh formulasi geplak yang disukai konsumen sehingga inovasi produk baru ini nantinya dapat dikembangkan menjadi makanan khas daerah.

\section{Rosela}

Rosela merupakan herba tahunan yang bisa mencapai ketinggian 0,5-3 meter. batangnya bulat, tegak, berkayu dan berwarna merah. Tanaman ini mempunyai nama ilmiah Hibiscus sabdariffa Linn., termasuk famili Malvaceae. Rosela dapat tumbuh baik di daerah tropis dan subtropis. Tanaman ini mempunyai habitat asli di daerah terbentang dari India hingga Malaysia. Namun, sekarang tanaman ini telah tersebar luas di daerah tropis dan subtropis di seluruh dunia. Karena itu, tanaman ini mempunyai nama umum yang berbeda di berbagai negara antara lain roselle (Inggris), oseille rouge (Portugis), rosa de jamaica (Spanyol), vinagreira (Portugis), asam susur (Malaysia), dan zuring (Belanda).

Bunga rosela merupakan bunga tunggal, artinya setiap tangkai hanya satu bunga. Mahkota bunga berbentuk corong, tersiri dari 5 helaian, panjangnya $3-5 \mathrm{~cm}$. Bunga ini mempunyai 8-11 helai kelopak yang berbulu, panjangnya $1 \mathrm{~cm}$, pangkalnya saling berlekatan dan berwarna merah. Kelopak ini sering dianggap sebagai bunga oleh masyarakat. Bagian inilah yang sering dimanfaatkan sebagai bahan makanan dan minuman (Maryani dan Kristiana, 2005).

Penggunaan kelopak bunga rosela sebagai bahan makanan telah dimanfaatkan sebagai bahan makanan di berbagai negara. Di India Barat, kelopak rosela segar digunakan untuk pewarna dan perasa dalam membuat anggur rosela, jeli, sirup, gelatin, minuman segar, puding dan cake. Di Meksiko, kelopak rosela diolah menjadi minuman yang terkenal dengan sebutan summer drinks of Mexico. Minuman ini merupakan salah satu minuman segar terpolpuler di Meksiko

(Maryani dan Kristiana, 2005).

\section{BAHAN DAN METODE}

\section{Alat dan Bahan}

Bahan yang digunakan dalam penelitian ini meliputi bahan untuk membuat geplak secara umum yaitu gula pasir dan kelapa. Sedangkan bahan lain adalah kelopak bunga rosela organik. Kelopak bunga berasal dari Kelompok Tani SEGER ASRI di wilayah Jelok, Cepogo, Boyolali. Bahan tambahan meliputi kelapa, gula pasir dan garam. Sedangkan peralatan yang digunakan dalam penelitian terdiri dari peralatan memasak dan peralatan gelas untuk analisis laboratorium.

Kelopak bunga rosela dalam penelitian ini digunakan untuk memberikan citarasa dan aroma dari geplak. Hal ini disebabkan pada umumnya geplak dibuat dari kelapa dengan citarasa tambahan dari essen serta pewarna tambahan. Selain itu rosela juga memberikan rasa asam dari geplak, yang selama ini manis menjadi produk yang asam, manis dan gurih.

\section{Pembuatan Geplak Rosela}

Geplak rosela dibuat dengan formulasi gula pasir 50\%; kelapa 20\%, kelopak bunga rosela $20 \%$, dan pepaya adalah $10 \%$. Proses pembuatan geplak adalah semua bahan tersebut dicampur menjadi satu kemudian dipanaskan dengan api sedang hingga adonan dapat dipulung. Setelah itu dicetak dalam kondisi adonan masih panas.

Pada penelitian dilakukan variasi terhadap pepaya yaitu pepaya mentah (setelah petik), mengkal dan pepaya masak. Pepaya merupakan bahan pengisi dan juga sebagai salah satu bahan pembentuk tekstur pada produk geplak.

\section{Analisis Sifat Sensoris}

Analisa sifat sensoris dilakukan dengan uji pembedaan dan uji kesukaan. Uji pembedaan digunakan untuk mengetahui perbedaan masing masing produk, sedangkan uji kesukaan diwakili oleh panelis. Untuk penilaian menggunakan scoring test. Parameter yang diukur dalam pengujian sensoris geplak rosela meliputi tekstur atau kekerasan, rasa, aroma, dan warna geplak. 


\section{HASIL DAN PEMBAHASAN}

\section{Sifat sensoris geplak rosela}

Geplak rosela merupakan produk geplak dengan penambahan kelopak bunga rosela sebagai ciri khas produk. Tujuan penambahan kelopak bunga rosela adalam untuk memberikan citarasa dan juga warna dari produk. Geplak rosela merupakan inovasi produk baru untuk geplak yang selama ini berasa manis menjadi produk yang berasa manis, asam dan gurih. Selain itu warna yang dihasilkan dari geplak rosela adalah merah karena warna alami dari kelopak bunga rosela merah.

Berdasarkan hasil penelitian sebelumnya (Maryani dan Kristiana, 2005) diketahui bahwa kelopak bunga rosela mengandung serat dan vitamin $C$ yang cukup tinggi. Selain itu warna merah merupakan antosianin yang juga berpotensi sebagai antioksidan. Oleh karena itu dengan penambahan rosela maka geplak rosela dimungkinkan dapat digunakan sebagai makanan kesehatan.

Berdasarkan hasil analisis uji sensoris dengan scoring test secara lengkap dapat dilihat dalam Tabel 1. Hasil penilaian tersebut merupakan rata-rata penilaian dengan Scoring test yang terdiri dari 25 panelis dan diuji secara statistik dengan menggunakan ANOVA yang dilanjutkan dengan LSD. Angka-angka yang diikuti dengan angka yang sama untuk menunjukkan intensitasnya.

Tabel 1. Hasil Penilaian Uji Pembedaan

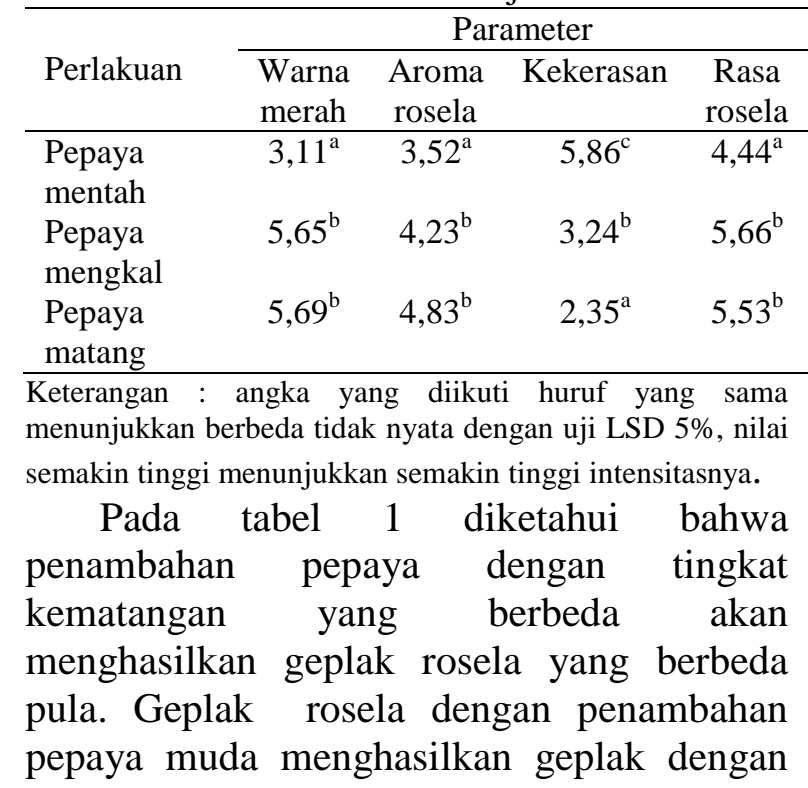

warna yang merah, mempunyai aroma rosela, tekstur yang sangat keras, dan mempunyai rasa khas rosela. Sedangkan geplak rosela dengan penambahan pepaya mengkal akan dihasilkan geplak rosela yang warnanya sangat merah, mempunyai aroma rosela yang kuat, tekstur keras dan rasa khas rosela lebih dibandingkan pepaya mentah. Sedangkan geplak rosela dengan penambahan pepaya matang dihasilkan geplak dengan warna, rasa dan aroma yang sama dengan geplak rosela dengan penambahan papaya mengkal, tetapi pada geplak dengan penambahan pepaya matang ini dihasilkan tekstur yang agak keras.

Perbedaan tekstur pada ketiga geplak rosela tersebut disebabkan karena tingkat kemasakan buah pepaya yang digunakan dalam penelitian berbeda. Semakin muda pepaya semakin tinggi kandungan pektin. Kandungan pektin yang semakin tinggi akan mengakibatkan tekstur yang semakin keras ketika geplak rosela menjadi dingin.

Selain itu juga disebabkan kandungan air produk geplak rosela yang semakin rendah dengan penggunaan pepaya yang semakin muda umurnya. Perbedaan kandungan air bahan dasar tersebut sangat mempengaruhi produk yang dihasilkan, karena dengan semakin tinggi kandungan airnya mengakibatkan geplak rosela yang dihasilkan mempunyai tingkat kekerasan yang semakin rendah

Tabel 2 menunjukkan hasil penilaian panelis terhadap produk. Penilaian tersebut merupakan rata-rata penilaian dengan Scoring test yang terdiri dari 40 panelis dan diuji secara statistik dengan menggunakan ANOVA yang dilanjutkan dengan LSD. Angka-angka yang diikuti dengan angka yang sama untuk menunjukkan tidak beda nyata pada $\alpha=0,05$. Semakin tinggi nilai parameter semakin disukai oleh panelis.

Dari hasil Scoring test tersebut dapat diketahui bahwa semakin matang pepaya yang digunakan akan mendapatkan penilaian yang berbeda dari panelis. Penilaian panelis terhadap warna menunjukkan bahwa geplak rosela yang dibuat dengan menggunakan pepaya mentah memperoleh nilai yang terendah jika dibandingkan dengan geplak pepaya yang menggunakan pepaya mengkal 
Tabel 2. Hasil Penilaian Uji Organoleptik Geplak Rosela

\begin{tabular}{lccccc}
\hline \multirow{2}{*}{ Perlakuan } & \multicolumn{5}{c}{ Parameter } \\
\cline { 2 - 6 } & $\begin{array}{c}\text { Warna } \\
\text { geplak } \\
\text { rosela }\end{array}$ & $\begin{array}{c}\text { Aroma } \\
\text { geplak } \\
\text { rosela }\end{array}$ & Tekstur & Rasa & Keseluruhan \\
\hline Pepaya mentah & $3,55^{\mathrm{a}}$ & $3,34^{\mathrm{a}}$ & $3,32^{\mathrm{a}}$ & $3,28^{\mathrm{a}}$ & $3,68^{\mathrm{a}}$ \\
Pepaya mengkal & $4,21^{\mathrm{b}}$ & $4,67^{\mathrm{b}}$ & $5,21^{\mathrm{b}}$ & $5,72^{\mathrm{b}}$ & $5,55^{\mathrm{c}}$ \\
Pepaya matang & $4,45^{\mathrm{b}}$ & $4,63^{\mathrm{b}}$ & $3,27^{\mathrm{a}}$ & $5,47^{\mathrm{b}}$ & $4,69^{\mathrm{b}}$ \\
\hline
\end{tabular}

Keterangan : angka yang diikuti huruf yang sama menunjukkan berbeda tidak nyata dengan uji LSD 5\%, nilai semakin tinggi menunjukkan semakin tinggi tingkat kesukaan panelis terhadap geplak rosela.

dan pepaya matang. Dari tabel uji pembedaan dapat dilihat bahwa geplak dengan penambahan pepaya mengkal memiliki warna merah yang paling muda jika dibandingkan dengan kedua produk yang lain. Hal itu menunjukkan bahwa panelis lebih menyukai geplak rosela yang berwarna merah tua seperi warna kelopak bunga rosela.

Hasil penilaian kesukaan terhadap aroma geplak rosela menunjukkan bahwa geplak rosela dengan penambahan pepaya mengkal disukai oleh panelis, dan geplak rosela dengan penambahan pepaya mengkal dan pepaya matang sangat disukai oleh panelis. Perbedaan aroma tersebut disebabkan oleh kadar air yang berbeda pada bahan, dengan kadar air yang semaik tinggi maka akan mengeluarkan aroma bahan-bahan pada pembuatan geplak yang menimbulkan aroma khas geplak rosela.

Hasil penilaian kesukaan terhadap tekstur geplak rosela menunjukkan bahwa geplak rosella dengan penambahan pepaya mental dan pepaya matang disukai oleh panelis, geplak rosela dengan penambahan pepaya mengkal paling disukai oleh panelis, karena geplak rosela yang dihasilkan tidak terlalu keras dan tidak terlalu lunak. Sedangkan geplak dengan penambahan pepaya mentah dihasilkan tekstur yang sangat keras, dan geplak dengan penambahan pepaya matang dihasilkan geplak dengan testur yang tidak keras.

Dari ketiga geplak rosela tersebut panelis paling menyukai geplak rosela dengan penambahan pepaya mengkal, baik dari warna, aroma, tekstur dan rasa geplak rosela. Geplak rosela dengan penambahan pepaya matang juga sangat disukai oleh panelis, dan geplak rosela dengan penambahan pepaya mentah disukai oleh panelis. Hal itu menunjukkan bahwa bahan baku akan mempengaruhi produk yang dihasilkan, sehingga pada pembuatan geplak rosela pemilihan bahan baku merupakan salah satu hal utama yang harus dilakukan.

\section{KESIMPULAN}

Berdasarkan hasil penelitian tentang sifat sensoris geplak rosela, maka dapat disimpulkan bahwa penambahan pepaya dengan tingkat kemasakan yang berbeda akan dihasilkan produk yang berbeda. Berdasarkan hasil uji sensoris diketahui bahwa geplak rosela dengan penambahan pepaya mengkal paling disukai konsumen.

\section{DAFTAR PUSTAKA}

Chen.2003. dalam: Maryani, $\mathrm{H}$ dan Kristiana, L. 2005. Khasiat dan Manfaat ROSELA. PT AgroMedia Pustaka. Jakarta

Herrera.A.A., Flores.R.S., Chavez.S.M.A. 2004. Effectiveness and Tolerability A Standardized Extract from Hibiscus sabdariffa in Patients With Mild to Moderate Hipertension. Phytomedicine., 11(5): 357-82. July. http://www.ncbi.nlm.nih.gov

Kirdpon.S., Nakorn .S.N., Kirdpon. W. 1994. Changes in Urinary Chemical Compotition in Healthy Volunteers after Consuming Rosella (Hibiscus sabdariffa Linn.). J.Med Assoc Thai, 77 (6): 31421, June, http://www.ncbi.nlm.nih.gov

Maryani, H dan Kristiana, L. 2005. Khasiat dan Manfaat ROSELA. PT AgroMedia Pustaka. Jakarta

Maryoto, A., 2007. Permen Jahe Kisah Panjang Kembang Gula. http://kisah belanja.blogspot.com (Download, 7 Januari 2009) 
Naland, H., 2004. Kombucha Teh Ajaib Pencegah \& Penyembuh Aneka Penyakit. Jakarta: P.T. Agro Media Pustaka, 37 hal.

Nurainy Fibra, 2007. Efek Penambahan Rumput Laut Terhadap Karakteristik Fruit Leather Sirsak. Lembaga Penelitian Universitas Lampung. Lampung
Odigie. 2003. dalam: Maryani, H dan Kristiana, L. 2005. Khasiat dan Manfaat ROSELA. PT AgroMedia Pustaka. Jakarta.

Suhartatik, N., L. Kurniawati, M. Karyantina, dan D. Khistanto, 2005. Potensi Antioksidan Kombucha. Hasil Penelitian (personel communication). Surakarta: FTP UNISRI. 